\title{
GLIMPSES AT THE SYRIA OF THE PRESENT.
}

[Adapted from the Juedische Literaturblatt of Magdeburg.]

By Rev. D. Temple.

The old Tyropæum valley, which cuts the city of Jerusalem from north to south and extends from the western hill of the city (the falsely so-called Mount Zion) to the hill of the Temple has been from most ancient times the industrial quarter. It is in these densely peopled lanes and streets that the degeneracy and decline of the Jewish people is most evident. By a long stay in the Orient one becomes accustomed to many things that are found here, and yet ever and again he is most unpleasantly surprised by unwholesome odors and accumulations of filth encountered in the narrow lanes of this quarter, swarming with an unwashed population. Numerous vaulted alleys and covered passage ways afford opportunity for this general filthiness, for in their obscure nooks and corners are piled together things of every kind in all stages of putrefaction and decay. In the eastern bazaar alley which extends in a southerly direction into the Jewish quarter are, if possible, greater accumulations of filth and refuse than elsewhere. Small work and antiquarian shops and wine rooms that are scarcely enticing, abound in this locality.

Disgusting to a stranger are the meat markets, which in unappetizing appearance and disease-breeding odors excel even those of the moslem bazaars. The ground near them is soaked with the blood of slaughtered animals; bloody heads of lambs and goats are piled in front of the markets, and hides as soon as removed are stretched upon the surface of the street in order to be tanned, in the easiest way, by the feet of the multitude that unceasingly passes.

The people of this quarter give the impression of a physically degenerate race. A pale, sickly look characterizes them all. The women are small and scantily built, generally with blonde or reddish hair and gray or light blue eyes. The cut of their clothing reminds one of European style, but the large white linen cloth, which they wind about the head, banishes from their appearance the last element of grace. Among the men there are occasionally found some of remarkably large stature, yet even these have a haggard look.

A very large portion of the Jews at Jerusalem live, as is well known, upon the charity of their wealthy European co-religionists 
without further occupation than the conduct of religious study and exercises. These last consist in maintaining regular prayers and are commonly carried on under the direction of their European benefactors.

Of Jewish craftsmen there are but few, chiefly stone cutters and workers in a limited way in metals. The Bazaars of Jerusalem are not to be compared with those of Cairo, or of Damascus. Excepting, perhaps, the products of certain saddlery and shoemaking establishments, there is nothing to be seen in their vaulted and gloomy shops that lays any claim to originality or good workmanship. It is evident enough that their stock in trade is designed exclusively for the poorest class of Jews, and for Bedouins. The grain and fruit markets with large heaps of various kinds of grain, are interesting. Here one meets many Bedouins from the Hawian and Jericho valley. Their women bring milk, cheese, oranges, lemons, cucumbers and olives to sell; and, at a convenient distance from their husband, sit down upon the ground with their wares before them in decorated metallic vessels, or upon palm-leaf baskets. Of inns for caravans Jerusalem has but few, a fact explained by the lack of extensive trade and industry.

The unwearying commercial spirit of the Jewish race is throughout Syria, checked by fear of the government to which, under an oppressive and exhausting system, a wealthy Jew is legitimate plunder. There is, however, in the city of Jerusalem a large number of small Jewish traders and merchants, and in respect to honesty and trustworthiness they stand in the same good repute as the modern Arabians,--a repute which the Christian merchants of Syria do not in general enjoy.

Among the Ashkenazim there are said to be at the present time a number of very wealthy families who have wandered to Jerusalem from other lands. Besides a first precaution to put themselves under the care of their consul, they take others also, and live in the simplest manner possible, avoiding all display which might draw upon them the eye of the Turkish government. The synagogues and numerous costly buildings for charitable institutions, erected here by the families of Rothschild and Montefiore, and by associations of large Jewish firms in England, France and Germany, have, during the last few years, extended considerably the Jewish quarter.

That a real improvement in the distressing state of the political relations of the Jews at Jerusalem would not be brought about by these lavish contributions of their co-religionists, was, and still is, perfectly 
clear to the persons whose interests are concerned. Upon the recognition of this fact was based the now almost forgotten scheme to found a great Syrio-Jewish colony in old Gilead and Moab. An area of 600,000 hektors, at present inhabited by nomadic Bedouins, was to be the territory of this new Jewish kingdom. At its head was to stand a a prince of Jewish race, but he was nevertheless to be under the supremacy of the Turkish government. The entire plan was laid before the Sultan by the English embassy, and no decided opposition was encountered. The initiatory steps toward compassing the financial part of the undertaking were successful. The scheme involved the construction of two railroads,- - one from Joppa to Jerusalem, the other from Haifa to the country beyond Jordan; and of a canal from the Mediterranean to the Gulf of Akabat. The leading spirit in this enterprise, which, as appears, aimed at financial rather than religious objects, is reputed to have been a well known English diplomat.

\section{NOTES FROM ABROAD.}

By Rev. John P. Peters, Ph. D.

M. Halevy has recently suggested an explanation of גִפרךך, the name of the Assyrian idol in whose temple Sanherib was murdered by his sons, so plausible as to appear almost self-evident when once suggested. It is known from the inscriptions that a favorite god of Sanherib was Nusuku. M. Halevy's suggestion is that נסרך (2 K. XIX., 37 , and Is. xxxviI., 38) is a clerical error for

There are to be two new instructors in Old Testament theology at Leipzig next semester, of whom one will be Dr. Wilh. Lotz, author of the valuable little work entitled Die Inschriften Tiglathpileser's I. His Habilitations-Schrift (thesis presented when he qualifies as instructor) is on the Sabbath, as to the origin of which in Babylonia he offers a very ingenious, if doubtful, explanation. The primary meaning of the root (Heb. Shabhath, Arab. Sabata) is cut off. The ancient Babylonian method of reckoning, derived from the non-Semitic, antecedent races, as was also the observance of the Sabbath itself, was by sixes. Business engagements were accordingly entered into for six days as the natural unit, and so a time-reckoning of six business days became established. That which separated one six days from another was the day of cutting off, or the sabbath, which was hence established as the day of complete rest-the day on which the king "shall not eat flesh cooked with fire, 